Berkunsky, I., M. V. Simoy, R. E. Cepeda, C. Marinelli, F. P. Kacoliris, G. Daniele, A. Cortelezzi, J. Diáz, J. Mateo Friedman, and R. M. Aramburú. 2015. Assessing the use of forest islands by parrot species in a neotropical savanna. Avian Conservation and Ecology 10(1): 11. http://dx.doi. org/10.5751/ACE-00753-100111

Copyright (C) 2015 by the author(s). Published here under license by the Resilience Alliance.

Research Paper

\title{
Assessing the use of forest islands by parrot species in a neotropical savanna
}

\author{
Igor Berkunsky ${ }^{1}$, María V. Simoy ${ }^{1}$, Rosana E. Cepeda ${ }^{1}$, Claudia Marinelli ${ }^{1}$, Federico P. Kacoliris ${ }^{2}$, Gonzalo Daniele ${ }^{2}$, Agustina \\ Cortelezzi ${ }^{1}$, José A. Díaz-Luque ${ }^{3}$, Juan Mateo Friedman ${ }^{1}$ and Rosana M. Aramburú ${ }^{4}$ \\ ${ }^{1}$ Instituto Multidisciplinario sobre Ecosistemas y Desarrollo Sustentable, Universidad Nacional del Centro de la Provincia de \\ Buenos Aires, ${ }^{2}$ Facultad de Ciencias Naturales y Museo, Universidad Nacional de la Plata, ${ }^{3}$ Proyecto de Conservación Paraba \\ Barba Azul, World Parrot Trust, Beni, Bolivia, ${ }^{4}$ División Zoología Vertebrados, Facultad de Ciencias Naturales y Museo, \\ Universidad Nacional de la Plata
}

\begin{abstract}
Understanding the effect of habitat fragmentation is a fundamental yet complicated aim of many ecological studies. Beni savanna is a naturally fragmented forest habitat, where forest islands exhibit variation in resources and threats. To understand how the availability of resources and threats affect the use of forest islands by parrots, we applied occupancy modeling to quantify use and detection probabilities for 12 parrot species on 60 forest islands. The presence of urucuri (Attalea phalerata) and macaw (Acrocomia aculeata) palms, the number of tree cavities on the islands, and the presence of selective logging, and fire were included as covariates associated with availability of resources and threats. The model-selection analysis indicated that both resources and threats variables explained the use of forest islands by parrots. For most species, the best models confirmed predictions. The number of cavities was positively associated with use of forest islands by 11 species. The area of the island and the presence of macaw palm showed a positive association with the probability of use by seven and five species, respectively, while selective logging and fire showed a negative association with five and six species, respectively. The Blue-throated Macaw (Ara glaucogularis), the critically endangered parrot species endemic to our study area, was the only species that showed a negative association with both threats. Monitoring continues to be essential to evaluate conservation and management actions of parrot populations. Understanding of how species are using this natural fragmented habitat will help determine which fragments should be preserved and which conservation actions are needed.
\end{abstract}

\section{Évaluation de l'utilisation d'îles forestières par des espèces de perroquets dans une savane néotropicale}

RÉSUMÉ. La compréhension de l'effet de la fragmentation de l'habitat est l'objectif fondamental mais compliqué de nombreuses recherches en écologie. La savane de Beni est un milieu forestier naturellement fragmenté dans lequel les îles forestières diffèrent sur le plan des ressources et des menaces. Afin de comprendre à quel point la disponibilité des ressources et les menaces ont une influence sur l'utilisation d'îles forestières par les perroquets, nous avons appliqué des modèles de présence pour quantifier l'utilisation et la probabilité de détection de 12 espèces de perroquets sur 60 îles forestières. La présence de palmiers canne (Acrocomia aculeata) et de palmiers urucuri (Attalea phalerata), le nombre de cavités d'arbres sur les îles et la présence de coupes sélectives et de feu ont été inclus comme covariables associées à la disponibilité des ressources et aux menaces. L'analyse de la sélection de modèles a indiqué que les variables relatives aux ressources et celles relatives aux menaces expliquaient l'utilisation d'îles forestières par les perroquets. Pour la plupart des espèces de perroquets, les meilleurs modèles ont confirmé les prédictions. Le nombre de cavités était positivement associé avec l'utilisation d'îles forestières chez 11 espèces. La superficie de l'île et la présence de palmiers canne étaient positivement associées avec la probabilité d'utilisation chez 7 et 5 espèces, respectivement, tandis que la coupe sélective et le feu étaient négativement associés chez 5 et 6 espèces, respectivement. L'Ara canindé (Ara glaucogularis), espèce de perroquet en voie de disparition critique endémique à notre aire d'étude, a été la seule espèce qui a montré une association négative avec les deux menaces. Le suivi demeure essentiel pour l'évaluation des mesures de conservation et de gestion des populations de perroquets. La compréhension de l'utilisation de ce milieu naturellement fragmenté par les espèces contribuera à déterminer quelles parcelles devraient être protégées et quelles mesures de conservation sont nécessaires.

Key Words: Bolivia; habitat use; macaw; occupancy model

Address of Correspondent: Igor Berkunsky, Paraje Arroyo Seco S/n, Campus Universitario, Tandil, Buenos Aires, Argentina, 7000 ,

igorberkunsky@gmail.com 


\section{INTRODUCTION}

The effect of habitat fragmentation for any species depends on the scale of fragmentation relative to the "scale of the individual organism" (Keitt et al. 1997). Differential responses to fragmentation may be caused by behavioral differences that determine space use and movement patterns of the organisms (Ims 1995). Characteristics such as site fidelity, dispersal ability, colonization capacity, and habitat specialization also influence the vulnerability of species to habitat fragmentation (Ewers and Didham 2006, Mapelli and Kittlein 2009, Dennis et al. 2012).

The high mobility of most parrot species allows them to use, or at least reach, small remnants within fragmented landscapes (Fischer and Lindenmayer 2002, Manning et al. 2007, Nunes and Galetti 2007, Monterrubio-Rico et al. 2010) which less-mobile species cannot access (Villard and Taylor 1994). This ability allows parrots to use heterogeneous habitats. During a single day, a parrot can use several fragments for different purposes (i.e., foraging, roosting, and nesting) (Gilardi and Munn 1998, Burger and Gochfeld 2003, Symes and Perrin 2003, Ríos-Muñoz and Navarro-Sigüenza 2009). In addition, habitat use can change seasonally in response to food availability; however, philopatry to roosting and nesting sites is high, especially during the breeding season, when most parrots spend a large amount of time at nesting sites (Bjork and Noss 2004, Ndithia and Perrin 2006, Stahala 2008, Berkunsky and Reboreda 2009). As a result of these variable behaviors, habitat studies must account for changes in detectability (Manning et al. 2006, Gibson et al. 2007).

Beni savannas of north Bolivia are the habitat of 23 parrot species, including the critically endangered Blue-throated Macaw (Ara glaucogularis) (Hennessey et al. 2003). The whole region has been identified as a stronghold for lowland parrot species, especially macaws, and research on the status, population sizes, and habitat use of parrots in the area has been identified as a priority for conservation (Herzog et al. 2005, Larrea-Alcázar et al. 2011). As occurs in other neotropical savannas, palms and scattered trees are more common than forests. Forest habitat in Beni savannas is naturally fragmented and limited to forest islands and riverine gallery forests (Langstroth Plotkin and Riding 2011). However, the quality of natural fragments of forest has been notably reduced, and the most basic data for effective conservation management decisions (i.e., the spatial distribution of threatened species within these forest fragments) remain poorly documented (Mayle et al. 2007). In this regard, the identification of habitat variables that are associated with fragment use and turnover is essential to determine how habitat quality is affected by human activities.

In this study, we quantified differences in species' use of forest islands by conducting occupancy modeling for a community of parrot species in northern Bolivia. We examined habitat used by parrots in a series of forest islands that varied in size, availability of resources, and presence of threats. We tested a priori expectations of how the probability of use should vary with resource availability (cavities and palm tree species) and presence of threats on the forest island. We also tested how the probability of detection should vary with the time of sampling. The framework we present can be applied to estimate species' use of forest islands in a given region. The results of the model will help show that species are largely restricted to habitat characteristics and are thus most likely to be adversely affected by habitat loss.

\section{METHODS}

\section{Study site}

We conducted surveys of areas in Beni savannas (also called Llanos de Moxos), Beni department, northern Bolivia. The Beni savannas is a $160,000 \mathrm{~km}^{2}$ expanse of seasonally inundated area, interspersed with a complex mosaic of forest islands and riverine gallery forests; it occupies the extremely flat Beni-Mamoré-Iténez basin in southwest Amazonia, which is situated between the Precambrian Shield to the east and the Andes to the west and south (Mayle et al. 2007). Numerous whitewater rivers and hundreds of shallow, flat-bottomed lakes cover the landscape. Mean annual precipitation varies from 1300 to $2000 \mathrm{~mm}$ across the region, and occurs mainly between September and May (Hanagarth and Beck 1996).

The landscape is dominated by flat, low-lying areas that are covered by completely open, treeless savanna and are seasonally inundated (Langstroth 1996). Forest islands are prominent features of the Moxos landscapes and largely represent palaeolevee remnants surrounded by seasonally inundated grasslands. These islands are analogous to the "matas" of the Orinoco and the "capões" of the Pantanal (Langstroth Plotkin and Riding 2011). The characteristics of the savanna are not suitable for the development of row crop agriculture; as a result, cattle ranching is the primary economic activity (Mayle et al. 2007).

\section{Sampling approach}

In 2011, we surveyed 60 forest islands for the occurrence of parrot species. We conducted surveys in a 9-week time frame (between September 8 and November 9) during the end of the dry season. This period coincides with the start of the breeding season of most parrot species in the area. Teams of two or three observers combed a variable number of forest islands. Most surveys were conducted during the morning (from 0600 to 1000 hours) and the afternoon (from 1400 to 1800 hours). Furthermore, we registered the start time (as minutes since sunrise) and duration (minutes) of each visit to each forest island. To reduce the effect associated with the abilities of the observers, all surveys were conducted by trained observers.

For each surveyed forest island, we recorded area, parrot species, palm tree species, tree cavities, and evidence of human activities (i.e., presence of cattle, stumps, and burnt trees). Group size, and visual and vocal detections were recorded for all parrot species. Visual or vocal detections were the first clue to species' detection. Vocal detections often lead to visual detection.

We recorded the presence/absence of two large palm tree species: urucuri palm (Attalea phalerata, hereafter U-palm) and macaw palm (Acrocomia aculeata, hereafter M-palm), which are commonly used for food and nesting by most parrot species in the region (Yamashita and de Barros Machado 1997, Hesse and Duffield 2000). We also recorded the maximum number of detected tree cavities that could be used by parrots. For each cavity, we noted if it was in a live or dead tree. Ground surveys are inaccurate for estimating true cavity abundance; cavities that appear to be useable, from the ground, are not actually suitable for wildlife (Cockle et al. 2010). Although ground-based surveys provide inaccurate cavity counts, they are useful for assessing 
relative rather than true cavity abundance, which is valuable in selecting habitat trees for retention in production forests (Koch 2008).

We identified four main habitat threats on forest islands: cattle, selective logging, fire, and deforestation. Signs used to identify habitat threats included burnt trees, cut stumps, and cattle feces and tracks. The dominant economic activity in the region is cattle ranching (Mayle et al. 2007). It has a direct impact on forest recruitment due to browsing of saplings (Scariot et al. 2008), and represents an indirect threat because it is associated with people living and working in the field. People burn the savanna to produce grazing land, and fires usually destroy trees on islands, which reduces the availability of food and cavities. Ranchers also extract wood from forest fragments for fences and pens (Langstroth 1996). This kind of selective logging is a high-impact threat because it reduces key sources of food and high-quality nesting sites.

\section{Analysis}

Large palm trees are assumed to be a key resource for macaw and parrot species (Yamashita and de Barros Machado 1997); thus, we included the presence of the two common large palmsurucuri and macaw palms - as covariates in the models. We included the presence of selective logging and fire as covariates of habitat threats. Cattle and deforestation were excluded from the analysis because they showed a small variation.

If cavity density on the forest island were constant, then the number of detected cavities per time unit would be constant, and the total number of cavities would be determined by the size of the forest island. However, we failed to detect evidence supporting this assumption: we did not observe this constant relationship (Fig. 1). Since the size of the island did not reflect the availability of cavities, we used the number of detected cavities on the island as the nesting resource availability variable. We assumed that detection errors in this covariate were not biased estimates.

Occupancy $(\psi)$ was defined as the proportion of sites occupied, and detection probability $(p)$ was the probability that a species would be detected within a sample area, given that it was present within that sample area. Our estimates of detection probability were conditional on both the presence of a species and the availability of that species during the count period (Bailey et al. 2013). We used the package unmarked in $\mathrm{R}$ (Fiske and Chandler 2011) to analyze our occupancy data, which allowed us to compare models using Akaike's information criterion (AIC) (Burnham and Anderson 2002). This information-theoretic approach allowed us to assess the influence of covariates on occupancy and detection probability by examining the evidence from a set of competing models (Burnham and Anderson 2002). Although access problems and time constraints prevented us from completing three visits to 46 of the 60 forest islands, missing observations are acceptable and accommodated in single-season models (MacKenzie and Bailey 2004).

Although we used a traditional single-season occupancy model, in our case, the closure assumption was not met (i.e., sites are closed to changes in occupancy). Parrots move between forest islands in the area they are occupying (I. Berkunsky, personal observation). If parrot species randomly moved in and out of a sampling unit (i.e., a forest island), the occupancy estimator should be interpreted as the proportion of forest islands "used" by the target parrot species (MacKenzie et al. 2005, Bailey et al. 2013). The probability of detecting a parrot species on a forest island in a given survey is defined as the product of the probability that the species uses the forest island during the season, and the probability of detecting the species during the survey, given that it was physically present on the forest island.

Fig. 1. Number of detected cavities per time and size of surveyed forest islands in northern Bolivia.

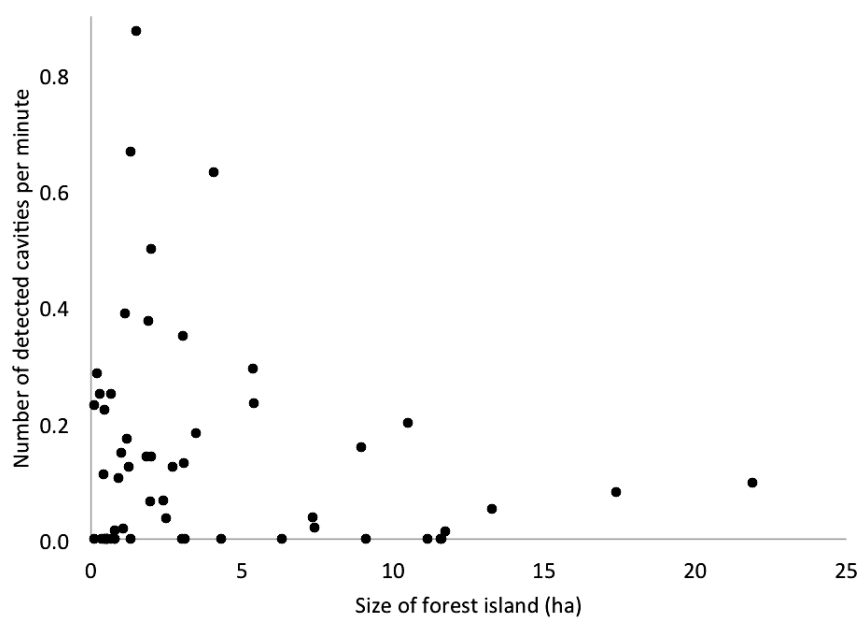

We developed a model set based on a priori hypotheses that use of forest islands by parrot species may be affected by resource availability (area of the island, number of cavities, and presence of large palms) and presence of threats (logging and fire) (Table 1). We considered only models with two to six parameters (including the intercept and probability of detection) to avoid the occurrence of spurious results by maintaining an approximate ratio of data to parameters $>10(n=60$ sites; maximum number of parameters $=n / 10)$ (Burnham and Anderson 2002). We first fitted the data to a baseline model in which "use" was constant across all islands and did not vary with any island-specific covariates [denoted as $\psi($.$) ]. We hypothesized that the probability$ of use would be higher on (a) large islands, and (b) islands with more resources (cavities and palm species). We also hypothesized that habitat threats would affect the use of forest islands. Finally, we modeled the covariates of use in various combinations, totaling 56 different models for each species.

The detection probability $(p)$ may differ by the period of time that an individual is physically present on an island. Therefore, we modeled detection relative to start time, and hypothesized that surveys late in the day would have lower probability of detection. To examine this effect, we ran the 56 models but allowed $p$ to vary with start time.

To identify which covariates in our models were good predictors of use of forest islands, we assessed the strength of evidence from our model-selection results and from modeled estimates of covariates effects. First, we examined whether the best models in the set were better than constant-occupancy models [i.e., $\psi($.$) ...].$ 
Table 1. Variables and hypothesis proposed in the modeling of use of 60 forest islands of Beni savannas, Bolivia by 12 parrot species.

\begin{tabular}{|c|c|c|c|}
\hline & Variable & Description & Hypothesis \\
\hline \multirow[t]{4}{*}{ Resources } & Area & Estimated size of forest island (ha) & Habitat availability $(+)$ \\
\hline & Cavities & Number of detected cavities & Nesting habitat $(+)$ \\
\hline & U-palm & Presence of urucuri palm (Atthalea phalerata) & Foraging and nesting $(+)$ \\
\hline & M-palm & Presence of macaw palm (Acrocomia aculeata) & Foraging and nesting $(+)$ \\
\hline \multirow[t]{2}{*}{ Threats } & Logging & Evidence of selective logging & Habitat quality (-) \\
\hline & Fire & Evidence of fire activity & Habitat quality (-) \\
\hline Sampling & Start time & Time of the day of sampling (hours since sunrise) & Parrot's activity (-) \\
\hline
\end{tabular}

Next, we identified which covariates were consistently included in the set of $\mathrm{R}$ best models (i.e., models that were within two AIC units $[\triangle \mathrm{AIC}<2]$ of the top-supported model). For covariates, we calculated the estimates of parameters $(\beta)$ and their standard errors. For determining the overall level of support for each covariate (given the model set), we added the model weights for each of the respective models (Burnham and Anderson 2002). Instead of reporting $\beta$ estimates from a single best model, we report model-averaged $\beta$ and their standard errors to account for uncertainty in the model-selection process. Model-averaged estimates are a weighted average of all the estimates of a particular covariate across the $\mathrm{R}$ best models containing that covariate, weighted by each model's Akaike weight (Burnham and Anderson 2002). We considered estimates whose interval (model-averaged estimates $\pm \mathrm{SE}$ ) did not overlap zero to provide strong evidence of a covariate's effect. Covariates whose intervals were nearly centered on zero provided little evidence of such an effect.

\section{RESULTS}

\section{Detection}

We detected 12 parrot species on 60 surveyed forest islands. Median global group size was two individuals. In all species, most individuals were detected vocally $(89.2 \pm 0.1 \%)$ (Table 2$)$. Median sampling effort was $7.6 \mathrm{~min} / \mathrm{ha}($ mean $=11.8, \mathrm{SE}=1.2)$. Most sampling efforts $(95 \%)$ were less than $33.3 \mathrm{~min} / \mathrm{ha}$.

All top-ranked models for White-eyed Parakeet and Peachfronted Parakeet, and some top-ranked models for another nine species, included start time as a covariate for detection (Table 3). Model-averaged estimates indicated that increasing delays in start time had a negative effect on the probability of detecting eight parrot species (Table 4).

\section{Use}

The size of forest islands ranged from 0.10 to 89.5 ha $($ mean $=$ $7.7, \mathrm{SE}=2.02)$. Most forest islands $(90 \%)$ were less than 14 ha (Fig. 2).

We detected cavities on two-thirds (41 of 60) of the forest islands. Most cavities (43\%) were in U-palm. All cavities in U-palm and caranday wax palm (Copernicia alba), and most cavities $(80 \%)$ in M-palm, were in dead trees. An opposite relationship was observed in hardwood trees, where only $10 \%$ of cavities were in dead trees. We observed the joint presence of the three species of palm tree on one-third of the forest islands (21 of 60).
Table 2. Group size and percentage of vocal detections for 12 parrot species in Beni savannas, northern Bolivia.

\begin{tabular}{lcc}
\hline \hline Species & $\begin{array}{c}\text { Detected group } \\
\text { size } \\
\text { min-max } \\
\text { (median) }\end{array}$ & $\begin{array}{c}\text { Vocal detections } \\
\text { percentage } \\
(n)\end{array}$ \\
\hline $\begin{array}{l}\text { Blue-throated Macaw } \\
\text { Ara glaucogularis) }\end{array}$ & $1-10(2)$ & $89 \%(27)$ \\
$\begin{array}{l}\text { Blue-and-yellow Macaw } \\
\text { (Ara ararauna) }\end{array}$ & $1-18(2)$ & $77 \%(93)$ \\
$\begin{array}{l}\text { Red-and-green Macaw } \\
\text { (Ara chloropterus) }\end{array}$ & $1-2(2)$ & $93 \%(14)$ \\
$\begin{array}{l}\text { Chestnut-fronted Macaw } \\
\text { (Ara severus) }\end{array}$ & $1-9(2)$ & $85 \%(59)$ \\
$\begin{array}{l}\text { Yellow-collared Macaw } \\
\text { (Primolius auricollis) }\end{array}$ & $1-4(2)$ & $86 \%(21)$ \\
$\begin{array}{l}\text { Turquoise-fronted Amazon } \\
\text { (Amazona aestiva) }\end{array}$ & $1-14(2)$ & $90 \%(71)$ \\
$\begin{array}{l}\text { Scaly-headed Parrot } \\
\text { (Pionus maximiliani) }\end{array}$ & $1-4(2)$ & $63 \%(8)$ \\
$\begin{array}{l}\text { White-eyed Parakeet } \\
\text { Psittacara leucophtalmus) }\end{array}$ & $1-42(4)$ & $82 \%(45)$ \\
$\begin{array}{l}\text { Peach-fronted Parakeet } \\
\text { (Eupsittula aurea) }\end{array}$ & $1-23(2)$ & $93 \%(41)$ \\
$\begin{array}{l}\text { Dusky-headed Parakeet } \\
\text { (Aratinga wedellii) }\end{array}$ & $1-10(2)$ & $75 \%(59)$ \\
$\begin{array}{l}\text { Yellow-chevroned Parakeet } \\
\text { Brotogeris chiriri) }\end{array}$ & $1-300(3)$ & $89 \%(74)$ \\
$\begin{array}{l}\text { Blue-winged Parrotlet } \\
\text { Forpus xanthopterygius) }\end{array}$ & $1-30(2)$ & $75 \%(8)$ \\
\hline
\end{tabular}

Fig. 2. Area of surveyed islands in northern Bolivia.

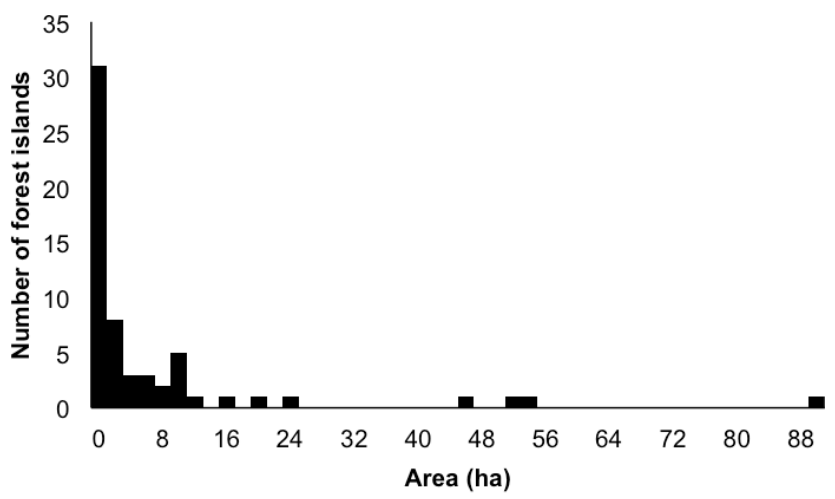


Avian Conservation and Ecology 10(1): 11

Table 3. Top performing site occupancy models $(\triangle \mathrm{AIC}<2)$ of 12 parrot species within forest islands of Beni savannas, northern Bolivia.

\begin{tabular}{|c|c|c|c|c|}
\hline Species & Model & $\Delta \mathrm{AIC}$ & $\mathrm{w}_{\mathrm{i}}$ & $\begin{array}{l}-2 \log \\
\text { Likelihood }\end{array}$ \\
\hline \multirow[t]{8}{*}{ Blue-throated Macaw } & $\Psi($ cavities + M-palm) p (.) & 0.00 & 0.20 & 65.69 \\
\hline & $\Psi$ (cavities + M-palm + fire) $\mathrm{p}()$. & 0.12 & 0.19 & 63.81 \\
\hline & $\Psi($ cavities + fire $) \mathrm{p}()$. & 0.56 & 0.15 & 66.25 \\
\hline & $\Psi$ (cavities) $\mathrm{p}()$. & 0.89 & 0.13 & 68.57 \\
\hline & $\Psi($ area + cavities + M-palm $) \mathrm{p}()$. & 1.72 & 0.09 & 65.41 \\
\hline & $\Psi($ cavities + M-palm) p (time) & 1.73 & 0.09 & 65.42 \\
\hline & $\Psi($ cavities + M-palm + fire $) \mathrm{p}($ time $)$ & 1.90 & 0.08 & 63.58 \\
\hline & $\Psi$ (cavities + M-palm + logging) $\mathrm{p}()$. & 1.96 & 0.08 & 63.65 \\
\hline \multirow[t]{5}{*}{ Blue-and-yellow Macaw } & $\Psi($ cavities + logging) $\mathrm{p}()$. & 0.00 & 0.34 & 101.11 \\
\hline & $\Psi$ (cavities + logging + fire) $\mathrm{p}()$. & 0.93 & 0.22 & 100.04 \\
\hline & $\Psi$ (area + cavities + logging) $\mathrm{p}()$. & 1.29 & 0.18 & 100.39 \\
\hline & $\Psi($ cavities + logging $) \mathrm{p}($ time $)$ & 1.91 & 0.13 & 101.02 \\
\hline & $\Psi$ (cavities + M-palm + logging) $\mathrm{p}()$. & 1.94 & 0.13 & 101.05 \\
\hline \multirow[t]{5}{*}{ Red-and-green Macaw } & $\Psi($ area + cavities + M-palm + logging) p (.) & 0.00 & 0.30 & 36.47 \\
\hline & $\Psi($ area + cavities + M-palm $) \mathrm{p}()$. & 0.04 & 0.29 & 38.51 \\
\hline & $\Psi($ area + cavities + M-palm $) \mathrm{p}($ time $)$ & 1.07 & 0.17 & 37.54 \\
\hline & $\Psi($ area + cavities + M-palm + logging $) \mathrm{p}($ time $)$ & 1.76 & 0.12 & 36.23 \\
\hline & $\Psi($ area + cavities + M-palm + fire $) \mathrm{p}()$. & 1.96 & 0.11 & 38.44 \\
\hline \multirow[t]{4}{*}{ Chestnut-fronted Macaw } & $\Psi$ (cavities + M-palm) p (.) & 0.00 & 0.30 & 97.41 \\
\hline & $\Psi$ (cavities) $\mathrm{p}()$. & 0.75 & 0.27 & 99.65 \\
\hline & $\Psi$ (cavities + M-palm + fire) $\mathrm{p}()$. & 1.09 & 0.23 & 95.98 \\
\hline & $\Psi$ (cavities + M-palm + logging) p (.) & 1.31 & 0.20 & 96.21 \\
\hline \multirow[t]{6}{*}{ Yellow-collared Macaw } & $\Psi($ area + logging + fire $) \mathrm{p}()$. & 0.00 & 0.37 & 89.24 \\
\hline & $\Psi$ (cavities) $\mathrm{p}()$. & 0.23 & 0.33 & 93.47 \\
\hline & $\Psi(.) \mathrm{p}()$. & 0.49 & 0.29 & 95.73 \\
\hline & $\Psi($ area + fire $) \mathrm{p}()$. & 0.78 & 0.02 & 92.03 \\
\hline & $\Psi($ area + logging + fire $) \mathrm{p}($ time $)$ & 1.76 & 0.01 & 89.00 \\
\hline & $\Psi($ area + M-palm + logging + fire $) \mathrm{p}()$. & 1.79 & 0.01 & 89.04 \\
\hline \multirow[t]{13}{*}{ Turquoise-fronted Amazon } & $\Psi$ (cavities + fire) $\mathrm{p}()$. & 0.00 & 0.13 & 113.93 \\
\hline & $\Psi($ cavities + M-palm + fire $) \mathrm{p}()$. & 0.09 & 0.12 & 112.02 \\
\hline & $\Psi($ area + cavities + M-palm + fire $) \mathrm{p}()$. & 0.36 & 0.11 & 110.29 \\
\hline & $\Psi($ cavities $+\mathrm{M}$-palm + fire $) \mathrm{p}($ time $)$ & 0.64 & 0.09 & 110.58 \\
\hline & $\Psi($ area + cavities + fire $) \mathrm{p}()$. & 0.74 & 0.09 & 112.67 \\
\hline & $\Psi($ cavities + fire $) \mathrm{p}($ time $)$ & 0.83 & 0.08 & 112.76 \\
\hline & $\Psi$ (cavities + logging + fire $) \mathrm{p}()$. & 1.26 & 0.07 & 113.19 \\
\hline & $\Psi($ area + cavities + logging + fire $) \mathrm{p}($ time $)$ & 1.38 & 0.06 & 109.31 \\
\hline & $\Psi($ area + cavities + logging + fire $) \mathrm{p}()$. & 1.40 & 0.06 & 111.34 \\
\hline & $\Psi$ (cavities + M-palm + logging + fire $) \mathrm{p}()$. & 1.81 & 0.05 & 111.74 \\
\hline & $\Psi($ cavities + U-palm + M-palm + fire $)$ p (.) & 1.99 & 0.05 & 111.92 \\
\hline & $\Psi($ area + cavities + fire $) \mathrm{p}($ time $)$ & 2.00 & 0.05 & 111.93 \\
\hline & $\Psi$ (cavities + U-palm + fire) p (.) & 2.00 & 0.05 & 113.93 \\
\hline \multirow[t]{9}{*}{ Scaly-headed Parrot } & $\Psi$ (cavities) $\mathrm{p}()$. & 0.00 & 0.19 & 48.83 \\
\hline & $\Psi$ (cavities + logging) $\mathrm{p}()$. & 0.08 & 0.18 & 46.91 \\
\hline & $\Psi$ (cavities + M-palm + logging) $\mathrm{p}()$. & 1.18 & 0.10 & 46.01 \\
\hline & $\Psi$ (cavities) p (time) & 1.21 & 0.10 & 48.05 \\
\hline & $\Psi$ (cavities + logging) $\mathrm{p}($ time $)$ & 1.35 & 0.10 & 46.18 \\
\hline & $\Psi($ cavities + fire $) \mathrm{p}()$. & 1.39 & 0.09 & 48.22 \\
\hline & $\Psi$ (cavities + M-palm) p (.) & 1.59 & 0.08 & 48.42 \\
\hline & $\Psi$ (cavities + logging + fire $) \mathrm{p}()$. & 1.67 & 0.08 & 46.50 \\
\hline & $\Psi($ area + cavities $) \mathrm{p}()$. & 1.99 & 0.07 & 48.83 \\
\hline \multirow[t]{2}{*}{ White-eyed Parakeet } & $\Psi($ area + cavities + logging $) \mathrm{p}($ time $)$ & 0.00 & 0.64 & 79.19 \\
\hline & $\Psi($ area + cavities $) \mathrm{p}($ time $)$ & 1.16 & 0.36 & 82.35 \\
\hline \multirow[t]{3}{*}{ Peach-fronted Parakeet } & $\Psi($ area + fire $) \mathrm{p}($ time $)$ & 0.00 & 0.55 & 115.67 \\
\hline & $\Psi($ area + cavities + fire $) \mathrm{p}($ time $)$ & 0.78 & 0.25 & 115.22 \\
\hline & $\Psi($ area + logging + fire $) \mathrm{p}($ time $)$ & 1.27 & 0.20 & 115.66 \\
\hline \multirow[t]{4}{*}{ Dusky-headed Parakeet } & $\Psi(.) \mathrm{p}()$. & 0.00 & 0.04 & 96.52 \\
\hline & $\Psi$ (fire) $\mathrm{p}()$. & 0.29 & 0.03 & 94.81 \\
\hline & $\Psi$ (cavities) p $()$. & 0.30 & 0.03 & 94.82 \\
\hline & $\Psi$ (cavities + fire) $\mathrm{p}()$. & 0.73 & 0.02 & 93.25 \\
\hline
\end{tabular}




\begin{tabular}{|c|c|c|c|c|}
\hline & $\Psi(\mathrm{M}-$ palm) $\mathrm{p}()$. & 1.37 & 0.02 & 95.89 \\
\hline & $\Psi($ area) $\mathrm{p}()$. & 1.74 & 0.01 & 96.26 \\
\hline & $\Psi$ (logging) $\mathrm{p}()$. & 1.77 & 0.01 & 96.29 \\
\hline & $\Psi($ area + fire $) \mathrm{p}()$. & 1.80 & 0.01 & 94.32 \\
\hline & $\Psi(.) \mathrm{p}$ (time) & 1.88 & 0.01 & 96.40 \\
\hline & $\Psi$ (cavities + M-palm) p (.) & 1.93 & 0.01 & 94.45 \\
\hline \multirow[t]{6}{*}{ Yellow-chevroned Parakeet } & $\Psi$ (area + cavities) $\mathrm{p}()$. & 0.00 & 0.34 & 125.02 \\
\hline & $\Psi($ area + cavities + logging) $\mathrm{p}()$. & 1.57 & 0.15 & 124.59 \\
\hline & $\Psi($ area + cavities + fire $) \mathrm{p}()$. & 1.88 & 0.13 & 124.90 \\
\hline & $\Psi($ area + cavities $) \mathrm{p}$ (time) & 1.90 & 0.13 & 124.92 \\
\hline & $\Psi($ area + cavities + M-palm $) \mathrm{p}()$. & 1.96 & 0.13 & 124.99 \\
\hline & $\Psi($ area + cavities + U-palm) p (.) & 1.97 & 0.13 & 124.99 \\
\hline \multirow[t]{4}{*}{ Blue-winged Parrotlet } & $\Psi($ cavities + fire $) \mathrm{p}()$. & 0.00 & 0.38 & 64.46 \\
\hline & $\Psi($ area + cavities $) \mathrm{p}()$. & 0.28 & 0.33 & 64.75 \\
\hline & $\Psi$ (cavities + fire) $\mathrm{p}$ (time) & 1.87 & 0.15 & 64.33 \\
\hline & $\Psi($ area + cavities + fire $) \mathrm{p}()$. & 1.88 & 0.15 & 64.34 \\
\hline
\end{tabular}

Cattle were the most common threat on forest islands $(85 \%)$, followed by selective logging (67\%) and fire (35\%). Deforestation was uncommon on the surveyed islands $(3 \%)$.

The model-selection analysis for most species indicated that both resources and threats variables explained the use of forest islands by parrots (Tables 3 and 4).

Eight occupancy models for Blue-throated Macaw received strong support. Cavities were included in all top models, and M-palm was included in six of them. Only these two variables were included in the best model. Probability of use of forest islands was positively related to area, cavities, and M-palm, and was negatively related to fire and logging parameters. Parameter estimates for cavities had confidence intervals that did not overlap zero, indicating a consistent positive effect on probability of use (Fig. 3). In the best model, forest islands with M-palm were 1.2 to 4.7 times more likely to be used than islands without M-palm. Confidence intervals for parameter estimates of the rest of covariates overlapped zero, indicating that the direction of the effect was not always positive or negative.

Five occupancy models for Blue-and-yellow Macaw received strong support. U-palm was the only covariate absent in the top model set. Cavities and logging were the covariates in the best model, and they were included in all top models. Probability of use of forest islands was positively related to cavities, M-palm, and logging, and was negatively related to area and fire parameters. Parameter estimates for cavities and logging had confidence intervals that did not overlap zero (Fig 3.).

Five occupancy models for Red-and-green Macaw received strong support. U-palm was the only covariate absent in the top model set. Cavities, area, M-palm, and logging were the covariates in the best model. Also, cavities, area, and M-palm were included in all top models. Probability of use of forest islands was positively related to cavities and logging, and was negatively related to area, M-palm, and fire parameters. All model-averaged estimates had confidence intervals that overlapped zero.

Four occupancy models for Chestnut-fronted Macaw received strong support. Area and U-palm were absent in the top model set. Cavities and M-palm were the covariates in the best model, and cavities were included in all top models. Probability of use of forest islands was positively related to cavities and logging, and

was negatively related to M-palm and fire parameters. Parameter estimates for cavities had confidence intervals that did not overlap zero (Fig. 3).

Fig. 3. Influence of number of cavities on probability of use for the five parrot species for which cavities had a substantial effect. Probabilities were estimated by using the best model of each parrot species and the following values of covariates: Bluethroated and Chestnut-fronted Macaws in the presence of Mpalm, Turquoise-fronted Amazon in the absence of fire, Blueand-yellow Macaw in the presence of selective logging, and White-eyed Parakeet on an average size island in the presence of logging.
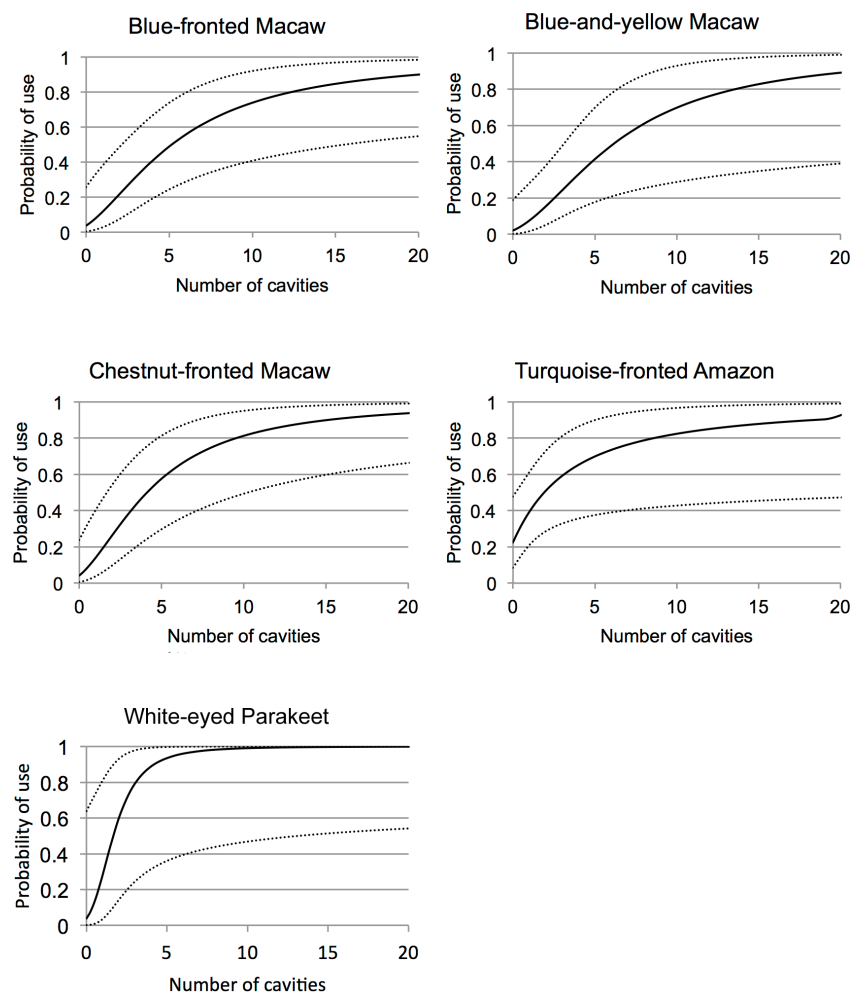
Table 4. Model-averaged parameter estimates, standard error (SE), and $90 \%$ confidence intervals $(\mathrm{CI})$ of top-ranked models $(\Delta \mathrm{AIC}<$ 2) for 12 parrot species within forest islands of Beni savannas, northern Bolivia. Estimates and standard error are on the logit scale.

\begin{tabular}{|c|c|c|c|c|c|}
\hline Species & & Estimate & $\mathrm{SE}$ & Lower CI & Upper CI \\
\hline \multirow[t]{8}{*}{ Blue-throated Macaw } & $\Psi$ intercept & -4.53 & 1.44 & -6.90 & -2.17 \\
\hline & Area & 0.29 & 0.71 & -0.87 & 1.46 \\
\hline & Cavities $^{\dagger}$ & 4.47 & 1.60 & 1.84 & 7.11 \\
\hline & M-palm & 1.57 & 0.99 & -0.06 & 3.20 \\
\hline & Logging & -0.21 & 1.12 & -2.06 & 1.64 \\
\hline & Fire & -1.46 & 1.07 & -3.22 & 0.31 \\
\hline & $p$ intercept & 0.98 & 0.52 & 0.13 & 1.84 \\
\hline & Time & -0.20 & 0.39 & -0.84 & 0.45 \\
\hline \multirow[t]{8}{*}{ Blue-and-yellow Macaw } & $\Psi$ intercept & -4.68 & 1.79 & -7.63 & -1.74 \\
\hline & Area & -0.76 & 0.60 & -1.75 & 0.23 \\
\hline & Cavities $^{\dagger}$ & 6.74 & 2.12 & 3.25 & 10.23 \\
\hline & M-palm & 0.26 & 1.10 & -1.54 & 2.07 \\
\hline & Logging $^{\dagger}$ & 2.60 & 1.43 & 0.24 & 4.95 \\
\hline & Fire & 1.22 & 1.22 & -0.79 & 3.22 \\
\hline & $p$ intercept & 0.79 & 0.32 & 0.27 & 1.32 \\
\hline & Time & -0.07 & 0.25 & -0.48 & 0.33 \\
\hline \multirow[t]{8}{*}{ Red-and-green Macaw } & $\Psi$ intercept & -7.14 & 4.77 & -14.98 & 0.71 \\
\hline & Area & -2.08 & 1.80 & -5.04 & 0.88 \\
\hline & Cavities & 8.96 & 6.52 & -1.76 & 19.68 \\
\hline & M-palm & -3.79 & 3.13 & -8.94 & 1.36 \\
\hline & Logging & 2.78 & 2.39 & -1.15 & 6.70 \\
\hline & Fire & -0.36 & 1.36 & -2.59 & 1.87 \\
\hline & $p$ intercept & 0.56 & 0.83 & -0.80 & 1.92 \\
\hline & Time & -0.46 & 0.54 & -1.35 & 0.44 \\
\hline \multirow[t]{6}{*}{ Chestnut-fronted Macaw } & $\Psi$ intercept & -2.12 & 0.86 & -3.54 & -0.70 \\
\hline & Cavities $^{\dagger}$ & 4.40 & 1.32 & 2.23 & 6.56 \\
\hline & M-palm & -1.35 & 0.88 & -2.81 & 0.11 \\
\hline & Logging & 1.05 & 0.98 & -0.56 & 2.66 \\
\hline & Fire & -1.08 & 0.93 & -2.61 & 0.45 \\
\hline & $p$ intercept & 0.95 & 0.38 & 0.32 & 1.58 \\
\hline \multirow[t]{8}{*}{ Yellow-collared Macaw } & $\Psi$ intercept & -1.16 & 6.59 & -11.99 & 9.67 \\
\hline & Area & 4.07 & 6.01 & -5.81 & 13.95 \\
\hline & Cavities & 2.19 & 2.15 & -1.34 & 5.72 \\
\hline & M-palm & 0.82 & 1.74 & -2.05 & 3.68 \\
\hline & Logging & 6.29 & 11.21 & -12.14 & 24.73 \\
\hline & Fire & 5.26 & 9.29 & -10.03 & 20.54 \\
\hline & $p$ intercept & -1.07 & 0.64 & -2.12 & -0.02 \\
\hline & Time & 0.13 & 0.27 & -0.31 & 0.58 \\
\hline \multirow[t]{9}{*}{ Turquoise-fronted Amazon } & $\Psi$ intercept & -1.29 & 0.94 & -2.84 & 0.26 \\
\hline & Area & -0.56 & 0.46 & -1.31 & 0.19 \\
\hline & Cavities $^{\dagger}$ & 3.15 & 1.36 & 0.91 & 5.39 \\
\hline & U-palm & 0.24 & 1.54 & -2.30 & 2.78 \\
\hline & M-palm & -1.26 & 0.95 & -2.82 & 0.30 \\
\hline & Logging & -0.95 & 1.22 & -2.96 & 1.05 \\
\hline & Fire & 2.15 & 1.13 & 0.30 & 4.01 \\
\hline & $p$ intercept & 0.70 & 0.33 & 0.16 & 1.24 \\
\hline & Time & -0.30 & 0.28 & -0.76 & 0.16 \\
\hline \multirow[t]{8}{*}{ Scaly-headed Parrot } & $\Psi$ intercept & -3.68 & 1.67 & -6.42 & -0.93 \\
\hline & Area & 0.01 & 0.41 & -0.67 & 0.69 \\
\hline & Cavities & 4.33 & 2.77 & -0.22 & 8.89 \\
\hline & M-palm & 1.27 & 1.46 & -1.14 & 3.68 \\
\hline & Logging & -2.59 & 2.30 & -6.37 & 1.19 \\
\hline & Fire & 0.95 & 1.44 & -1.42 & 3.32 \\
\hline & $p$ intercept & -0.39 & 0.83 & -1.76 & 0.98 \\
\hline & Time & -0.41 & 0.49 & -1.22 & 0.40 \\
\hline \multirow[t]{4}{*}{ White-eyed Parakeet } & $\Psi$ intercept & -0.76 & 2.21 & -4.39 & 2.88 \\
\hline & Area & 5.07 & 3.57 & -0.80 & 10.94 \\
\hline & Cavities $^{\dagger}$ & 6.63 & 3.28 & 1.23 & 12.04 \\
\hline & Logging & -3.45 & 2.75 & -7.97 & 1.07 \\
\hline
\end{tabular}




\begin{tabular}{|c|c|c|c|c|c|}
\hline & $p$ intercept & -0.37 & 0.36 & -0.95 & 0.22 \\
\hline & Time $^{\dagger}$ & -0.60 & 0.36 & -1.19 & -0.01 \\
\hline \multirow[t]{7}{*}{ Peach-fronted Parakeet } & $\Psi$ intercept & 0.10 & 0.77 & -1.16 & 1.36 \\
\hline & Area & 1.27 & 1.04 & -0.45 & 2.98 \\
\hline & Cavities & 0.87 & 1.30 & -1.28 & 3.01 \\
\hline & Logging & -0.07 & 1.20 & -2.04 & 1.90 \\
\hline & Fire & 2.32 & 1.86 & -0.74 & 5.37 \\
\hline & $p$ intercept & -0.01 & 0.35 & -0.59 & 0.57 \\
\hline & Time $^{\dagger}$ & -0.58 & 0.31 & -1.08 & -0.08 \\
\hline \multirow[t]{8}{*}{ Dusky-headed Parakeet } & $\Psi$ intercept & 0.51 & 1.91 & -2.64 & 3.66 \\
\hline & Area & -0.28 & 0.47 & -1.04 & 0.49 \\
\hline & Cavities & -1.73 & 2.27 & -5.47 & 2.00 \\
\hline & M-palm & 0.72 & 0.98 & -0.89 & 2.34 \\
\hline & Logging & 0.52 & 1.07 & -1.24 & 2.29 \\
\hline & Fire & -1.45 & 1.56 & -4.02 & 1.13 \\
\hline & $p$ intercept & -0.76 & 0.55 & -1.65 & 0.14 \\
\hline & Time & -0.11 & 0.33 & -0.65 & 0.42 \\
\hline \multirow[t]{9}{*}{ Yellow-chevroned Parakeet } & $\Psi$ intercept & 2.30 & 2.96 & -2.56 & 7.16 \\
\hline & Area & 7.26 & 6.53 & -3.49 & 18.00 \\
\hline & Cavities & 2.03 & 1.52 & -0.47 & 4.52 \\
\hline & U-palm & -0.31 & 1.82 & -3.31 & 2.68 \\
\hline & M-palm & -0.21 & 1.10 & -2.02 & 1.60 \\
\hline & Logging & 0.72 & 1.14 & -1.16 & 2.60 \\
\hline & Fire & -0.43 & 1.26 & -2.49 & 1.64 \\
\hline & $p$ intercept & 0.09 & 0.30 & -0.40 & 0.59 \\
\hline & Time & 0.08 & 0.25 & -0.33 & 0.49 \\
\hline \multirow[t]{6}{*}{ Blue-winged Parrotlet } & $\Psi$ intercept & 0.09 & 2.18 & -3.50 & 3.69 \\
\hline & Area & 1.17 & 3.92 & -5.27 & 7.61 \\
\hline & Cavities & 1.57 & 2.38 & -2.34 & 5.49 \\
\hline & Fire & -1.55 & 1.84 & -4.57 & 1.48 \\
\hline & $p$ intercept & -1.69 & 0.68 & -2.80 & -0.58 \\
\hline & Time & 0.12 & 0.34 & -0.43 & 0.68 \\
\hline
\end{tabular}

${ }^{\dagger}$ Estimates with intervals that did not overlap zero.

Six occupancy models (including the null model) for Yellowcollared Macaw received strong support. Area, logging, and fire were the covariates in the best model. Nerveless, the best model was only 0.5 AIC units higher than the null model. Modelaveraged estimates had confidence intervals that overlapped zero.

Thirteen occupancy models for Turquoise-fronted Amazon received strong support. All covariates were included in the top model set. Cavities and fire were the covariates in the best model, and both covariates were included in all top models. Probability of use of forest islands was positively related to cavities, U-palm, and fire, and was negatively related to area, M-palm, and logging parameters. Parameter estimates for cavities and fire had confidence intervals that did not overlap zero (Fig. 3).

Nine occupancy models for Scaly-headed Parrot received strong support. U-palm was absent in the top model set. Cavities was the only covariate in the best model, and it was included in all top models. Probability of use of forest islands was positively related to area, cavities, M-palm, and fire, and was negatively related to logging parameters. All model-averaged estimates had confidence intervals that overlapped zero.

Two occupancy models for White-eyed Parakeet received strong support. Area, cavities, and logging were the covariates in the best model. Probability of use of forest islands was positively related to area and cavities, and was negatively related to logging parameters. Parameter estimates for cavities had confidence intervals that did not overlap zero (Fig. 3).
Three occupancy models for Peach-fronted Parakeet received strong support. Area and fire were the covariates in the best model, and area was included in all top models. Probability of use of forest islands was positively related to area, cavities, and fire, and was negatively related to logging parameters. All model-averaged estimates had confidence intervals that overlapped zero.

Ten occupancy models for Dusky-headed Parakeet, including the null model, received strong support. The null model was the best one. Model-averaged estimates had confidence intervals that overlapped zero.

Six occupancy models for Yellow-chevroned Parakeet received strong support. Area and cavities were the covariates in the best model, and both covariates were included in all top models. Probability of use of forest islands was positively related to area, cavities, and logging, and was negatively related to U-palm, Mpalm, and fire parameters. All model-averaged estimates had confidence intervals that overlapped zero.

Four occupancy models for Blue-winged Parrotlet received strong support. Cavities and fire were the covariates in the best model, and cavities were included in all top models. Probability of use of forest islands was positively related to area and cavities, and was negatively related to fire parameters. All model-averaged estimates had confidence intervals that overlapped zero.

Table 5 summarizes the relationships between our hypotheses and the model-averaged estimates for the 12 species. The number of cavities and use of forest islands were positively associated in 
almost all species. Moreover, the model-averaged estimate for cavities did not overlap zero, providing strong evidence of a positive effect of cavities on the probability of use for five parrot species (Table 4, Fig. 3). The presence of U-palm was not associated with use of forest islands by 10 parrot species.

Table 5. Summary of relationships between hypotheses and the model-averaged estimates for 12 parrot species on 60 forest islands of Beni savannas, Bolivia. The number of species for which intervals of estimates did not overlap zero is shown in parentheses.

\begin{tabular}{lccc}
\hline \hline Variable-Hypothesis & \multicolumn{3}{c}{ Relationship } \\
\cline { 2 - 4 } & Expected & Unexpected & Unobserved \\
\hline Resources & 7 & 4 & 1 \\
$\quad$ Area - Habitat availability (+) & $11(5)$ & 1 & \\
Cavities - Nesting habitat (+) & 1 & 1 & 10 \\
U-palm - Foraging and nesting (+) & 5 & 4 & 3 \\
M-palm - Foraging and nesting (+) & & & \\
Threats & 5 & $6(1)$ & 1 \\
$\quad$ Logging - Habitat quality (-) & 6 & $5(1)$ & 1 \\
$\quad$ Fire - Habitat quality (-) & & & \\
Sampling & $8(2)$ & 3 & 1 \\
$\quad$ Start time - Parrot's activity (-) & & &
\end{tabular}

\section{DISCUSSION}

Forest islands are the habitat of a great number of parrot species of Beni savannas, including the critically endangered Bluethroated Macaw. Forest islands showed variation in size, availability of resources (i.e., presence of palm species and number of cavities), and presence of threats. This heterogeneity in habitat quality explained the use of forest islands by parrot species.

In our study area, the parrot community is comprised of 12 species. We detected most species characteristic of Beni savannas, but failed to detect 11 other species reported in this habitat (Hennessey et al. 2003, Maillard et al. 2008). Some of these species are only occasional visitors to savannas (e.g., Ara macao, Pionites leucogaster, Pionopsitta barrabandi, Pionus menstruus, Amazona amazonica, Amazona farinosa), and are regionally scarce (e.g., Diopsittaca nobilis, Aliopsitta xanthops) or usually occur in wide gallery forests along large rivers (e.g., Brotogeris cyanoptera).

\section{Detection}

As in other parrot studies, most detections were vocal (90\%), and the median group size was two individuals for each species (Casagrande and Beissinger 1997, Lee and Marsden 2012). Parrot detection was high at sunrise and decreased throughout the day. Most species confirmed our hypothesis by showing a negative effect of survey start time on the probability of detection. Only three species (i.e., Yellow-collared Macaw, Yellow-chevroned Parakeet, Blue-winged Parrotlet) showed a positive relationship between survey start time and probability of detection. This could be a consequence of constant activity during the day, a common behavior of small parrots, such as parakeets and parrotlets (Gilardi and Munn 1998).

\section{Use}

Forest islands sustain key food and nesting resources for a large number of parrot species. Large palms, urucuri and macaw palms, provide food and cavities for many parrot species, especially large macaws (Yamashita and de Barros Machado 1997). Both palm species were present jointly in at least half of the surveyed islands. The number of cavities was highly variable and unrelated to the area of the forest island. We detected cavities in both hardwood and palm tree species. An important consideration is the time that a cavity is available for use. Cavities in live trees tend to be more durable, and they are common in hardwood trees (Cockle et al. 2012). Cavities in palm trees were almost exclusively in dead trees. In humid forests, snags frequently undergo a rapid decay; thus, cavities are available for nesting during a short period of time, usually a couple of years (Cornelius et al. 2008).

The presence of threats on islands was variable, but most forest islands were exposed to cattle ranching. We found recent evidence of fire activity on at least one-third of forest islands. This is alarming given the impact that this threat has on the habitat of the islands (Skarpe 1992). Moreover, the growing vegetation tends to mask evidence of the oldest fires, which makes their detection more difficult (Soares 1990). Therefore, the number of forest islands affected by fires could have been underestimated. We detected selective logging on two-thirds of the forest islands. This is another concern because this threat creates a high impact by reducing key sources of food and cavities. Fortunately, another high-impact threat, deforestation for agriculture, was very rare.

For only two species (Yellow-collared Macaw and Dusky-headed Parakeet), the constant use model was included in the set of top models. For the other species, at least one model received substantially more support (i.e., $\Delta \mathrm{AIC}>2$ ) than the constant model.

The number of cavities present affected the use of forest islands by parrots. For 11 of 12 species, the number of cavities was positively associated with the probability of use. This relationship was especially strong for Blue-throated Macaw, Blue-and-yellow Macaw, Chestnut-fronted Macaw, Turquoise-fronted Amazon, and White-eyed Parakeet. For these species, islands with more than five cavities showed probabilities of use greater than 0.5 ; this value increased up to 0.9 on islands that had more than 15 cavities (Fig. 3). Only the Dusky-headed Parakeet showed a negative relationship between cavities on the island and use. In the study area, Dusky-headed Parakeet uses cavities in caranday wax palm for nesting; this palm is more common in open woodlands outside the forest islands (I. Berkunsky, personal observation). Therefore, the number of cavities would be a key factor associated with the use of forest islands by at least large- and medium-sized parrot species.

Our hypothesis about a positive relationship between forest island size and use was sustained by seven parrot species, resulting in a high probability of use on large forest islands. However, small islands seem to be important for some parrot and macaw species. Four species (Blue-and-yellow Macaw, Red-and-green Macaw, Turquoise-fronted Amazon, and Dusky-headed Parakeet) showed an inverse relationship with forest island size. Small islands would maintain a low density of predators, an attractive feature that could explain this preference by some parrot species (Monterrubio-Rico et al. 2009).

Our hypothesized association between large palms and use of islands by parrots was partially confirmed. The U-palm was present on most forest islands. This lack of variation could mask 
its effect, as covariate on the use of islands by parrots, being absent in almost all top-ranked models. In the case of M-palm, its presence would explain part of the use of forest islands by five parrot species: Blue-throated Macaw, Blue-and-yellow Macaw, Yellow-collared Macaw, Scaly-headed Parrot, and Dusky-headed Parakeet. M-palm is a common food and nesting resource for many neotropical parrots (Yamashita and de Barros Machado 1997, Ragusa-Netto 2006, Berkunsky et al. 2014).

Ten of 12 parrot species showed a negative association with at least one of the threats (i.e., selective logging or fire). Bluethroated Macaw, the single threatened parrot species in our study area, was the only species that confirmed our hypothesis that threats showed a negative association with both selective logging and fire. We also detected positive associations between threats and probability of use. In these cases, it is possible that our proposed variables are not good indicators of habitat quality, and/ or we failed to detect evidence of threats (i.e., old fires and stumps masked by growing vegetation). Another explanation is that the single presence of evidence is not enough to produce a significant loss of habitat quality. Finally, as occurs in other regions, parrots could be showing a behavioral plasticity by using humanmodified sites (Marsden and Pilgrim 2003, Salinas-Melgoza et al. 2013).

Our objective was to provide information on site-scale and landscape-scale parrot habitat relationships that would be broadly applicable to managed parrot populations in naturally fragmented landscapes of northern Bolivia. Our study has revealed one important consideration for parrot studies: habitat quality on forest islands (i.e., resources and threats) is heterogeneous and not always associated with the size of the island. Therefore, the use of variables associated with availability of resources and threats, instead of size of the island, seems more appropriate. By examining how this habitat heterogeneity explained the use of islands by parrots, we gained the ability to make inferences at a broad geographic scale. We suggest that (a) an effective parrot monitoring program could be improved by using a more theoretically sound approach that combined repeated count surveys that included the joint presence of parrots and resources, and (b) particular care must be taken when estimates of range are based on extrapolations that assume homogeneity of forest islands or fragments.

Forest islands are a key habitat for a good number of parrot species of Beni savannas. Understanding how parrot species are using this natural fragmented habitat will help determine which fragments should be preserved and which conservation actions are need. A rigorous monitoring program continues to be essential to informing conservation and management of parrots.

Responses to this article can be read online at:

http://www.ace-eco.org/issues/responses.php/753

\section{Acknowledgments:}

We thank P. Alvarez, F. Ávila, J. Casto Perez, C. Cuaino, V. Cuaino, C. Durán, J. Durán, R. Fernandez, L. González, H. Hoyos, R. Ibañez, R. Ibáñez, J. C. Lisboa, A. Nacif, J. Nacif, I. Natusch, H.
Parada, J. Rivero, A. Roca, E. Román, F. Román, J. Román, T. Salas, W. Villavicencio, P. Zabala, and R. Zabala for allowing us to work on their properties. We also acknowledge D. Añes, $N$. Franco, L. Gonzalez, and A.E. Rafael for their kind help and suggestions during fieldwork. This work was supported by Consejo Nacional de Investigaciones Científicas y Tecnológicas (CONICET PIP 112-20110-00358), ANPCyT (PICT 2011-0173), Universidad Nacional de La Plata (11/n572, 1/n702), The World Parrot Trust, Rufford Small Grants Foundation, Natural Encounters Conservation Fund, Keith Ewart Charitable Trust, HUGO BOSS-BOSS Orange, Macaw Landing Foundation, Mohammad Bin Zayed Species Conservation Fund, International Association of Avian Trainers and Educators, Minnesota Zoo, San Francisco Zoo, Point Defiance Zoo \& Aquarium, Idea Wild, Birder's Exchange, CREOI, and PICT 2011-0173 (FONCyT). We thank Fundación Noel Kempff Mercado, Consejo Nacional de Investigaciones Científicas y Tecnológicas (CONICET), Universidad Nacional de La Plata y Universidad Nacional del Centro de la Provincia de Buenos Aires. We also thank Dirección General de Biodiversidad y Áreas Protegidas (Viceministerio de Medio Ambiente y Aguas, Gobierno de Bolivia), Gobernación del Beni for institutional support. I. B. and F.K are Research Fellows of Consejo Nacional de Investigaciones Científicas y Técnicas de Argentina (CONICET).

\section{LITERATURE CITED}

Bailey, L. L., D. I. MacKenzie, and J. D. Nichols. 2013. Advances and applications of occupancy models. Methods in Ecology and Evolution 5:1269-1279. http://dx.doi.org/10.1111/2041-210x.12100

Berkunsky, I., G. Daniele, F. P. Kacoliris, J. A. Díaz-Luque, C. P. Silva Frías, R. M. Aramburú, and J. D. Gilardi. 2014. Reproductive parameters in the critically endangered Bluethroated Macaw: limits to the recovery of a parrot under intensive management. PLoS ONE 9:e99941. http://dx.doi.org/10.1371/ journal.pone.0099941

Berkunsky, I., and J. C. Reboreda. 2009. Nest-site fidelity and cavity reoccupation by Blue-fronted Parrots Amazona aestiva in the dry Chaco of Argentina. Ibis 151:145-150. http://dx.doi. org/10.1111/j.1474-919X.2008.00896.X

Bjork, R. D., and R. F. Noss. 2004. Delineating pattern and process in tropical lowlands: Mealy Parrot migration dynamics as a guide for regional conservation planning. Oregon State University, Corvallis, Oregon, USA.

Burger, J., and M. Gochfeld. 2003. Parrot behavior at a Río Manu (Perú) clay lick: temporal patterns, associations, and antipredator responses. Acta Ethologica 6:23-34. http://dx.doi.org/10.1007/ s10211-003-0080-y

Burnham, K. P., and D. R. Anderson. 2002. Model selection and multimodel inference: a practical information-theoretic approach. Springer-Verlag (Ed.). http://dx.doi.org/10.1007/b97636

Casagrande, D. G., and S. R. Beissinger. 1997. Evaluation of four methods for estimating parrot population size. Condor 99:445457. http://dx.doi.org/10.2307/1369951

Cockle, K. L., K. Martin, and M. C. Drever. 2010. Supply of treeholes limits nest density of cavity-nesting birds in primary and 
logged subtropical Atlantic forest. Biological Conservation 143:2851-2857. http://dx.doi.org/10.1016/j.biocon.2010.08.002

Cockle, K. L., K. Martin, and G. Robledo. 2012. Linking fungi, trees, and hole-using birds in a neotropical tree-cavity network: pathways of cavity production and implications for conservation. Forest Ecology and Management 264:210-219. http://dx.doi. org/10.1016/j.foreco.2011.10.015

Cornelius, C., K. Cockle, N. Politi, I. Berkunsky, L. Sandoval, V. Ojeda, L. Rivera, M. Hunter Jr., and K. Martin. 2008. Cavitynesting birds in neotropical forests: cavities as a potentially limiting resource. Ornitología Neotropical 19:253-268.

Dennis, R. L. H., P. B. Hardy, and L. Dapporto. 2012. Nestedness in island faunas: novel insights into island biogeography through butterfly community profiles of colonization ability and migration capacity. Journal of Biogeography 39:1412-1426. http:// dx.doi.org/10.1111/j.1365-2699.2012.02698.x

Ewers, R. M., and R. K. Didham. 2006. Confounding factors in the detection of species responses to habitat fragmentation. Biological Reviews 81:117-142. http://dx.doi.org/10.1017/ S1464793105006949

Fischer, J., and D. B. Lindenmayer. 2002. Small patches can be valuable for biodiversity conservation: two case studies on birds in southeastern Australia. Biological Conservation 106:129-136. http://dx.doi.org/10.1016/S0006-3207(01)00241-5

Fiske, I., and R. Chandler. 2011. Unmarked: an R package for fitting hierarchical models of wildlife occupancy and abundance. Journal of Statistical Software 43:1-23.

Gibson, L., B. Barrett, and A. Burbidge. 2007. Dealing with uncertain absences in habitat modelling: a case study rare grounddwelling parrot. Diversity and Distributions 13:704-713. http://dx. doi.org/10.1111/j.1472-4642.2007.00365.x

Gilardi, J. D., and C. A. Munn. 1998. Patterns of activity, flocking, and habitat use in parrots of the Peruvian Amazon. Condor 100:641-653. http://dx.doi.org/10.2307/1369745

Hanagarth, W., and S. G. Beck. 1996. Biogeographie der BeniSavannen (Bolivien). Geographische Rundschau 48:662-668.

Hennessey, A. B., S. K. Herzog, and F. Sagot. 2003. Lista anotada de las aves de Bolivia. Fifth edition. Armonía/BirdLife International, Santa Cruz de la Sierra, Bolivia.

Herzog, S. K., R. W. Soria Auza, and A. B. Hennessey. 2005. Ecoregional patterns of richness, endemism and threat of the Bolivian avifauna: priorities for ecoregional planning. Ecología en Bolivia 40:27-40.

Hesse, A. J., and G. E. Duffield. 2000. The status and conservation of the Blue-throated Macaw Ara glaucogularis. Bird Conservation International 10:255-275. http://dx.doi.org/10.1017/S0959270900000216

Ims, R. A. 1995. Movement patterns related to spatial structures. Pages 85-109 in L. Hansson, L. Fahrig, and G. Merriam, editors. Mosaic landscapes and ecological processes. Springer, Netherlands. http://dx.doi.org/10.1007/978-94-011-0717-4_4

Keitt, T. H., D. L. Urban, and B. T. Milne. 1997. Detecting critical scales in fragmented landscapes. Conservation Ecology 1:4. [online] URL: http://www.ecologyandsociety.org/vol1/iss1/art4/
Koch, A. J. 2008. Errors associated with two methods of assessing tree hollow occurrence and abundance in Eucalyptus obliqua forest, Tasmania. Forest Ecology and Management 255:674-685. http://dx.doi.org/10.1016/j.foreco.2007.09.042

Langstroth Plotkin, R., and S. Riding. 2011. Biogeography of the Llanos de Moxos: natural and anthropogenic determinants. Geographica Helvetica 66:183-192.

Langstroth, R. P. 1996. Forest islands in an Amazonian savannah of northeastern Bolivia. Dissertation. University of Wisconsin, Madison, Wisconsin, USA.

Larrea-Alcázar, D. M., D. Embert, L. F. Aguirre, B. Ríos-Uzeda, M. Quintanilla, and A. Vargas. 2011. Spatial patterns of biological diversity in a neotropical lowland savanna of northeastern Bolivia. Biodiversity and Conservation 20:11671182. http://dx.doi.org/10.1007/s10531-011-0021-4

Lee, A. T. K., and S. J. Marsden. 2012. The influence of habitat, season, and detectability on abundance estimates across an Amazonian parrot assemblage. Biotropica 44:537-544. http://dx. doi.org/10.1111/j.1744-7429.2011.00847.x

MacKenzie, D. I., and L. L. Bailey. 2004. Assessing the fit of siteoccupancy models. Journal of Agricultural, Biological, and Environmental Statistics 9:300-318. http://dx.doi.

org/10.1198/108571104X3361

MacKenzie, D. I., J. D. Nichols, J. A. Royle, K. H. Pollock, L. L. Bailey, and J. Hines. 2005. Occupancy estimation and modeling: inferring patterns and dynamics of species occurrence. Elsevier/ Academic Press, Burlington, Massachusetts, USA.

Maillard, O., J. Q. Vidoz, and M. Herrera. 2008. Registros significativos de aves para el Departamento del Beni, Bolivia: Parte 2. Kempffiana 4:8-12.

Manning, A. D., D. B. Lindenmayer, S. C. Barry, and H. A. Nix. 2006. Multi-scale site and landscape effects on the vulnerable superb parrot of south-eastern Australia during the breeding season. Landscape Ecology 21:1119-1133. http://dx.doi. org/10.1007/s10980-006-7248-6

Manning, A. D., D. B. Lindenmayer, S. C. Barry, and H. A. Nix. 2007. Large-scale spatial and temporal dynamics of the vulnerable and highly mobile superb parrot. Journal of Biogeography 34:289-304. http://dx.doi.org/10.1111/ j.1365-2699.2006.01603.x

Mapelli, F. J., and M. J. Kittlein. 2009. Influence of patch and landscape characteristics on the distribution of the subterranean rodent Ctenomys porteousi. Landscape Ecology 24:723-733. http://dx.doi.org/10.1007/s10980-009-9352-x

Marsden, S. J., and J. D. Pilgrim. 2003. Factors influencing the abundance of parrots and hornbills in pristine and disturbed forest on New Britain, PNG. Ibis 145:45-53. http://dx.doi. org/10.1046/j.1474-919X.2003.00107.x

Mayle, F. E., R. P. Langstroth, R. A. Fisher, and P. Meir. 2007. Long-term forest-savannah dynamics in the Bolivian Amazon: implications for conservation. Philosophical Transactions of the Royal Society B: Biological Sciences 362:291-307. http://dx.doi. org/10.1098/rstb.2006.1987 
Monterrubio-Rico, T. C., J. M. Ortega-Rodríguez, M. C. MarínTogo, A. Salinas-Melgoza, and K. Renton. 2009. Nesting habitat of the Lila-crowned Parrot in a modified landscape in Mexico. Biotropica 41:361-368. http://dx.doi.org/10.1111/j.1744-7429.2009.00493. $\mathrm{x}$

Monterrubio-Rico, T. C., K. Renton, J. M. Ortega-Rodríguez, A. Pérez-Arteaga, and R. Cancino-Murillo. 2010. The endangered Yellow-headed Parrot Amazona oratrix along the Pacific coast of Mexico. Oryx 44:602-609. http://dx.doi.org/10.1017/S0030605310000980

Ndithia, H., and M. R. Perrin. 2006. The spatial ecology of the Rosy-faced Lovebird Agapornis roseicollis in Namibia. Ostrich 77:52-57. http://dx.doi.org/10.2989/00306520609485508

Nunes, M. F. C., and M. Galetti. 2007. Use of forest fragments by Blue-winged Macaws (Primolius maracana) within a fragmented landscape. Biodiversity and Conservation 16:953-967. http://dx.doi.org/10.1007/s10531-006-9034-9

Ragusa-Netto, J. 2006. Dry fruits and the abundance of the Blueand-yellow Macaw (Ara ararauna) at a cerrado remnant in central Brazil. Ornitología Neotropical 17:491-500.

Ríos-Muñoz, C. A., and A. G. Navarro-Sigüenza. 2009. Effects of land use change on the hypothetical habitat availability for Mexican parrots. Ornitología Neotropical 20:491-509.

Salinas-Melgoza, A., V. Salinas-Melgoza, and T. F. Wright. 2013. Behavioral plasticity of a threatened parrot in human-modified landscapes. Biological Conservation 159:303-312. http://dx.doi. org/10.1016/j.biocon.2012.12.013

Scariot, A., D. L. M. Vieira, A. B. Sampaio, E. Guarino, and A. Sevilha. 2008. Recruitment of dry forest tree species in central Brazil pastures. Pages 231-244 in R. Myster, editor. Postagricultural succession in the neotropics. Springer, New York, USA. http://dx.doi.org/10.1007/978-0-387-33642-8_11

Skarpe, C. 1992. Dynamics of savanna ecosystems. Journal of Vegetation Science 3:293-300. http://dx.doi.org/10.2307/3235754

Soares, R. V. 1990. Fire in some tropical and subtropical South American vegetation types: an overview. Pages 63-81 in J. Goldammer, editor. Fire in the tropical biota. Springer- Verlag, Berlin, Heidelberg, Germany. http://dx.doi.org/10.1007/978-3-642-75395-4_5

Stahala, C. 2008. Seasonal movements of the Bahama Parrot (Amazona leucocephala bahamensis) between pine and hardwood forests: implications for habitat conservation. Ornitología Neotropical 19:165-171.

Symes, C. T., and M. R. Perrin. 2003. Daily flight activity and flocking behaviour patterns of the Greyheaded Parrot Poicephalus fuscicollis suahelicus Reichenow 1898 in Northern Province, South Africa. Tropical Zoology 16:47-62. http://dx.doi. org/10.1080/03946975.2003.10531183
Villard, M.-A., and P. D. Taylor. 1994. Tolerance to habitat fragmentation influences the colonization of new habitat by forest birds. Oecologia 98:393-401. http://dx.doi.org/10.1007/BF00324229

Yamashita, C., and Y. de Barros Machado. 1997. The Bluethroated Macaw Ara glaucogularis: characterization of its distinctive habitats in savannahs of the Beni, Bolivia. Ararajuba 5:141-150.
Editor-in-Chief: Keith A.Hobson

Subject Editor: Steven L.Van Wilgenburg
Sponsored by the Society of Canadian Ornithologists and Bird Studies Canada Parrainée par la Société des ornithologistes $d u$ Canada et Études d'oiseaux Canada

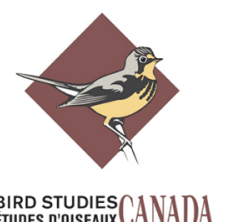

